\title{
PERAN IBU DALAM PENDIDIKAN KARAKTER ANAK USIA DINI MENURUT PANDANGAN ISLAM
}

\author{
$\underline{\text { Rianawati }}$ \\ Pusat Studi Gender dan Anak \\ Institut Agama Islam Negeri (IAIN) Pontianak
}

\begin{abstract}
The article elaborates the important roles of mothers in child's education. Nowadays, educational issues still becomes a trending topic and are often talked from many point of views, however, the most talked topic is about child's character building. Character psychologically guides a child to adapt to various environments. Besides, character becomes "a guide" to perform good or bad action. The character is also a factor whether the child be able to adapt to beterogeneous condition. Furthermore, mothers is truly a main educator to create a strong character in a child. Nevertheless, in a real life, there are still mothers who have not properly their job in educational issue. In order to grow the good character in a child, a mother should have a responsibility and proper knowledge. On the other hand, a mother should implement an educational method based on children's age. Moreover, an upbringing style in a family determines the success of the child's education.
\end{abstract}

Keywords:

Character, Mother, Upbringing Style, Ideology, Method

\section{PENDAHULUAN}

"Jangan jadikan alasan kesibukan sebagai tembok untuk memberikan hal yang terbaik untuk anak, tapi jadikanlah aktivitas sehari-hari menjadi ujian dalam mengukur dan menilai diri sebagai seorang ibu yang baik dan berkualitas," demikian Nila F. Moeloek.

Anak adalah amanah bagi kedua orang tuanya, kewajiban orang tua untuk memberikan pendidikan kepada anak merupakan urusan yang sangat berharga dan menempati prioritas tertinggi. Kalbu seorang anak yang masih bersih bak permata yang tidak ternilai harganya, bila ia dididik dan dibiasakan untuk melakukan kebaikan, niscaya dia akan tumbuh menjadi baik, sebaliknya bila ia dididik dan dibiasakan dengan perbuatan jelek, ia akan menjadi orang yang merugi dan celaka dunia akherat (Imam Ghazali dalam Kitab Ibya Ulumuddin).

Menurut pandangan Islam mengenai hak anak dalam mendapatkan pendidikan, sebetulnya terkait erat dengan tanggung jawab orang tua terhadap anaknya, orang tua (khususnya ibu) berkewajiban memberikan perhatian kepada anak dan dituntut untuk tidak lalai dalam mendidiknya. Jika anak merupakan amanah dari Allah Swt., otomatis mendidiknya termasuk bagian dari menunaikan amanahNya, Sebaliknya melalaikan hak-hak mereka termasuk khianat terhadap amanah Allah SWT., (Q.S An-Nisa:58).

Al-Asyamawi (dalam Hasan, 2004: 34-35), menjelaskan bahwa pendidikan ibu terhadap anak tentunya akan berguna nantinya untuk perkembangan anak kedepannya. Anak tidak hanya membutuhkan perlindungan dari ibunya, anak juga membutuhkan perhatian, belaian kasih sayang dan segenap bimbingan yang mereka butuhkan, bahwa anak adalah amanat yang dititipkan Tuhan YME kepada orang tua yang diamanatkan untuk dapat menjaga, membimbing, mengarahkan, dan mendidik anak semampunya mungkin. Menanamkan rasa keimanan kepada anak sejak usia dini, bukan berarti ibu mendidik mereka perasaan takut kepada Tuhan. Melainkan justru membuat anak merasa terlindungi. Semua ibu harus melakukan itu, supaya anak-anak selamat dari segala mara bahaya dunia akhirat.

Dalam mendidik anak, ibu diharapkan memberikan pengetahuan tentang keyakinan suatu agama sebagai suatu pedoman hidup. Ibu setidaknya memberi tahu bahwa hidup bukan hanya di dunia tetapi juga adanya kehidupan setelah mati. Ibu juga sebaiknya memberi tahu bahwa hidup 
adalah unuk beribadah sebagai rasa sukur kita telah ada di dunia. Dan anak sebaiknya diperkenalkan pada prinsip-prinsip Islam,

Seorang ibu juga harus menjadi model yang baik dan utama pada anak, karena keteladanan merupakan suatu pondasi dan pintu pertama. Jika ingin mencetak anak yang lurus, maka kita harus menghindarkan diri dari tingkah laku buruk.Peran ibu disini sangat penting karena ibu merupakan pendidik yang pertama dan utama, disamping itu ibu harus memberi contoh dan perilaku baik agar anak dapat meniru kebaikan dari ibunya. (Hasan, 2004 : 68).Setiap manusia pada dasarnya memiliki potensi untuk berkarakter sesuai dengan fitrah penciptaan manusia saat dilahirkan, akan tetapi dalam kehidupan kemudian memerlukan proses panjang pembentukan karakter melalui pengasuhan dan pendidikan sejak anak usia dini. Oleh karena itu pendidikan karakter sebagai usaha aktif untuk membentuk kebiasaan baik perlu ditanamkan terus sebagai sifat kebaikan anak sejak kecil.

Ketentuan umum Undang-undang No. 20 Tahun 2003 tetang Sistem Pendidikan Nasional poin 2 menyebutkan bahwa Pendidikan Nasional adalah pendidikan yang berdasarkan Pancasila dan UUD 1945 yang berakar pada nilai-nilai agama, kebudayaan nasional Indonesia dan tanggap terhadap tuntutan perubahan zaman. Selain itu dalam Bab II Pasal 3 disebutkan pula bahwa pendidikan nasional berfungsi mengembangkan kemampuan dan membentuk watak serta peradaban bangsa yang bermartabat dalam rangka mencerdaskan kehidupan bangsa bertujuan untuk berkembangnya potensi peserta didik agar menjadi manusia yang beriman dan bertaqwa kepada Tuhan Yang Maha Esa, berakhlak mulia, sehat, berilmu, cakap, kreatif, mandiri dan menjadi warga negara yang demokratis serta bertanggung jawab.

Dalam tujuan pendidikan nasional di atas menandakan bahwa yang menjadi bahan dalam praktik pendidikan hendaknya berbasis kepada seperangkat nilai sebagai panduan antara ranah kognitif, afektif dan psikomotor, bahkan tujuan pendidikan nasional yang utama menekankan pada aspek keimanan dan ketaqwaaan. Hal tersebut mengisyaratkan bahwa core value pembangunan karakter moral bangsa bersumber dari keyakinan beragama. Artinya semua proses pendidikan harus bermuara pada penguatan nilai-nilai ketuhanan sesuai dengan keyakinan agama yang diyakininya.

Praktik pendidikan pada jalur formal dewasa ini justru cenderung kurang memperhatikan esensi dari tujuan pendidikan nasioanal di atas, hal ini terbukti dengan kurang memadukannya nilainilai ketuhanan dalam proses pembelajaran yang dilaksanakannya, ironisnya justru lebih banyak berorientasi pada pengembangan struktur kognitif semata. Fenomena tersebut tentunya sangat bertentangan dan membuat jarak antara tujuan dan hasil pendidikan nasional semakin jauh. Berbagai fenomena tersebut dan semakin menggelindingnya proses dekadensi moral di kalangan generasi bangsa, semakin menunjukkan bahwa praktik pendidikan dewasa ini tidak bersandar pada amanah undang-undang yang mengisyaratkan pendidikan yang berbasis pada seperangkat nilai (pendidikan nilai) serta semakin penting dan mendesaknya pendidikan nilai.

Kenyataan lain juga menunjukkan bahwa masih banyak ibu yang lalai, lupa dan belum tahu cara melaksanakan tugas mendidik anak dengan baik .Kabanyakan ibu beranggapan kalau anakanak sudah diserahkan kepada guru di sekolah, maka selesailah tugas mereka dalam mendidik anak. Tugas mereka sekarang adalah mencari uang untuk membiayai sekolah anak-anak mereka. Sehingga tidak ada waktu lagi melakukan pembinaan akhlak pada anak-anak Pulang ke rumah sudah dalam keadaan letih. Pada akhirnya anak-anak tumbuh dan berkembang tanpa mendapatkan perhatian dari orang tua khususnya ibu. Anak-anak mencari kepribadiannya sendiri tanpa ada bimbingan ibu mereka. Itulah sebabnya maka banyak anak-anak yang kurang memiliki akhlakul karimah, seperti kurang memiliki rasa hormat pada orang tua, saudara dan gurunya. Jarang melaksanakan ibadah shalat di rumah atau di masjid, karena asyik bermain sampai sore hari.

Minimnya pengetahuan tentang pembinaan akhlak anak dan kelalaian ibu dalam mendidik akhlak anak akan menimbulkan persoalan yang besar pada anak. Seperti krisis akhlak akan terjadi pada anak, anak kurang memiliki akhlak terhadap Allah Swt, bersikap semaunya terhadap orang tua, saudara, kerabat, tetangga, teman dan siapa saja yang berhadapan dengannya. Dengan kata 
lain anak tidak memiliki adab dan tata karma dalam lingkungan pergaulan. Masalah yang lebih besar yang akan terjadi pada anak lagi yaitu anak akan terlibat dalam tindak dekadensi moral, dan tindak kriminalitas lainnya dan lebih parah lagi anak akan terlibat dalam narkoba dan miras.

\section{PEMBENTUKAN KARAKTER PADA DIRI ANAK}

Persoalan pendidikan yang terus masih menjadi "trending topic" dan sering dikaji dari berbagai sudut pandang adalah pembentukan karakter anak. Karakter merupakan suatu wadah dari berbagai psikologis yang membimbing anak untuk dapat menyesuaikan diri dengan beragam lingkungan yang dihadapi. Karakter menjadi "pemandu" untuk melakukan sesuatu yang baik dan benar atau sebaliknya. Karakter inilah juga menjadi penentu apakah anak mampu atau tidak menyesuaikan diri dengan heterogentitas kondisi yang dihadapi.

Pendidikan karakter adalah pendidikan budi pekerti yang mengkristal dengan pengetahuan (cognitive), perasaan (feeling) dan tindakan (action). Pendidkan karakter merupakan "panglima" kehidupan, menghindari split of personality (kerpibadian yang terpecah), yaitu belum mampu menyatukan perkataaan dengan perbuatan dan kesenjangan antara teori dan praktek, sebagian orang telah mengetahui dan memahami nilai-nilai atau ilmu tetapi masih minim dalam mempraktekkannya.Setiap orang harus membangun karakter secara solid, tetapi bagi orang yang belum dewasa dibutuhkan proses pendidikan. Dalam pandangan Koesoema (2007:202-217) ada lima unsur yang perlu dipertimbangkan dalam pendidikan karakter, yaitu a) mengajarkan b) keteladanan c) menentukan prioritas d) praktis prioritas dan e) refleksi. Proses ini sementara sifatnya hingga manusia muda itu cukup terrbentuk untuk berdiri dan berjalan sendiri. Kemudian untuk menggunakan karakter solid itu, manusia muda harus menggunakan budinya yang disadarkan dan diisi dengan nilai-nilai. Nilai-nilai ini tidak hanya diungkapkan dengan abstrak, tetapi dibutuhkan latihan yang praktis dan sistematis serta cukup lama

Perilaku anak merupakan akumulasi dari berbagai pembentukan aspek diri.Jika ditinjau dari sudut pandang Psikologi Perkembangan tentu saja karakter yang terbentuk bukanlah sesuatu yang tiba-tiba ada, namun merupakan hasil dari proses perjalanan hidup anak yang terbentuk dari kematangan biologis maupun perkembangan psikologis. Kematangan mengacu pada perubahanperubahan yang terjadi secara alamiah dan spontan, sementara itu perubahan yang terkait perkeembangan psikologis terkait dengan pengalaman belajar yang didapatkan dari lingkungan sekitarnya. Oleh karena itu satu hal yang perlu diperhatikan adalah bagaimana proses pendidikan dan pengassuhan yang didapatkan anak, sehingga membentuk pengalaman belajar yang bermakna bagi dirinya

Menurut Annis Matta, (2003: 67-70), menyebutkan beberapa kaidah atau strategi dalam pembentukkan karakter seorang muslim, yaitu sebagai berikut :

1. Kaidah kebertahapan, artinya proses perubahan, perbaikan, dan pengembangan harus dilakukan secara bertahap. Seorang anak dalam hal ini tidak bisa dituntut untuk berubah sesuai yang diinginkan secara tiba-tiba dan instan, namun ada tahapan-tahapan yang harus dilalui dengan sabar dan tidak terburu-buru. Adapun orientasi dari kegiatan ini adalah terlatak pada proses. Bukan pada hasil, akan tetapi membutuhkan waktu yang lama sehingga hasilnya nanti akan paten.

2. Kaidah kesinambungan, artinya perlu ada latihan yang dilakukan secara terus menerus. Seberapapun kecil porsi latihan, yang penting latihan itu berkesinambungan. Sebab proses yang berkesinambungan inilah nantinya akan membentuk rasa dan warna berpikir seseorang.

3. Kaidah motivasi instrinsik, artinya karakter anak terbentuk secara kuat dan sempurna jika didorong oleh keinginan sendiri, bukan karena paksaan dari orang lain. Jadi proses merasakan sendiri dan melakukan sendiri adalah penting. Hal ini sesuai dengan kaidah umum bahwa mencoba sesuatu akan berbeda hasilnya antara yang dilakukan sendiri dengan yang hanya dilihat atau diperdengarkan saja. Oleh karena itu pendidikan harus menanamkan motivasi yang kuat dan lurus serta melibatkan aksi fisik yang kuat, ini karena kedudukan seorang guru 
selain untuk memantau dan mengevaluasi perkembangan anak-anak, juga berfungsi sebagai unsur perekat, tempat curhat, dan sarana tukar pikiran bagi anak didiknya.

4. Kaidah pembimbing, artinya perlunya bantuan orang lain untuk mencapai hasil yang lebih baik daripada dilakukan seorang diri. Pembentukkan karakter ini tidak bisa dilakukan tanpa seorang guru atau pembimbing.

Pendidikan karakter anak, sebagaimana yang dijelaskan oleh Annis Matta di atas, bukan hal yang mudah. Sebaliknya pendidikan karakter memerlukan waktu dan proses yang sangat panjang dan bertahap untuk menuju suatu perubahan, dari yang tidak tahu dan tidak sadar, ditumbuhkan pengetahuan dan kesadaran, ditunjukkan bagaimana model melakukannya, dibimbing dan dinasehati, dibiasakan dan dikontrol agar karakter tumbuh dan berkembang dengan baik. Pembinaan karakter harus terus dilakukan secara kontinu, bertahap, dan berkesinambungan.

\section{Mendidik Karakter Anak Saat Masih dalam Kandungan}

Dalam mendidik karakter anak hendaklah dimulai ketika mereka masih dalam kandungan, karena sejak saat itu kedekatan emosional serta fisik ibu dan anak sudah terjalin secara alamiah. Tanpa disadari setiap perbuatan kita, baik ataupun buruk terekam oleh anak secara alami walaupun masih dalam kandungan. Menurut para ahli, kedekatan fisik dan emosional seorang ibu kepada anaknya merupakan salah satu aspek penting dalam keberhasilan pendidikan. Disinilah peran penting seorang ibu terhadaap anaknya di usia yang masih dini. Karena pendidikan seorang ibu terhadapa anaknya beerlangsung secara terus menerus, bahkan tidak pernah berhenti sampai ajal menjemput.

Anak cerdas, berprestasi dan berkahlak mulia, harus direncanakan secara terstrkutur dan sistematis sejak masih menjadi janin dalam kandungan calon sang ibu. Perencenaan ditindaklanjuti dengan tindakan langsung agar apa yang telah direncanakan tidak sia-sia. Beberapa hal yang harus dilakukan oleh sang ibu antara lain sebagaai berikut :Pertama, mengajak berbicara. Hasil penelitian menunjukkan, otak mulai terbentuk sejak 3 bulan. Pada usia 6 bulan, otak telah berkembang secara sempurna dan di usia tersebut, ibu bisa mengajak interaksi aktif. Salah satu interaksi yang dapat dilakukan seorang ibu dengan memberi nama dan mengajak berbicara. Janin akan terbiasa dengan Ibu, dan hal ini berdampak, pada saat anak kelak dewasa, anak akan lebih percaya diri.

Kedua, Makan makanan yang bergizi, menghindari diri dari makanan dan minuman yang membahayakan janin, dan istirahat yang cukup. Makanan sangat menentukan kualitas fisik seseorang. Begitupun janin yang mengalami tumbuh kembang fisiknya dalam kandungan seorang ibu, sangat membutuhkan makanan yang bergizi dan bernutrisi, berkualitas dan tentu saja halal. Makanan yang baik akan membentuk jasmani dan kesehatan yang baik pula pada fisik anak. Sebaliknya makanan yang tidak baik, akan mengganggu pertumbuhan dan perkembangan fisik janin. Selain itu, makanan yang halal dan thoyyiban sangat menentukan kepribadian anak saat dewasanya. Islam sangat menganjurkan agar orangtua memberi makanan yang baik dan halal. Sikap dan kepribadian turut ditentukan darimana sumber makanan diperoleh orang tuanya.

Ketiga, membaca dan mempelajari Al-Qur'an, Hadits, dan berbagai buku yang baik. Kebiasaan ibu membaca dan belajar akan berpengaruh pada sikap dan tumbuhkembang otak dan kecerdasan anak. Ketika anak lahir dan berkembang jasmaninya bulan ke bulan, kebiasaan membaca terus dilakukan ibu didepan anaknya. Apa yang dibaca ibu akan didengar oleh anak, baik ketika anak dalam kandungan atau pasca kelahiran. Pendengaran anak akan terlatih tajam dan apa yang didengar dari telinga anak selanjutnya diolah ke otaknya, dilakukan secara terus menerus yang akhirnya akan berpengaruh pada kecerdasannya. Kebiasaan ibu belajar dan membacapun akan menjadi model dan teladan pada anak. Kemungkinan besar, anak akan meniru kebiasaan ibu memegang buku, membaca dan mempelajarinya. Kebiasaan membaca dan belajarpun dilanjutkan pada anak usia balita, dengan memperkenalkan anak buku-buku yang sesuai dengan perkembangannya dan ibu membacakan isi cerita, memperkenalkan warna, bentuk gambar, angka, huruf dan apa saja isi buku pada anak.. 
Keempat, menjaga prilaku, menjaga prilaku sangat penting dan dibutuhkan pada masa kehamilan. Akhlak orang tua saangat berpengaruh terhadap akhlak anak-anaknya kelak, terutama ibu hamil. Mulai dari sikap, ucapan hingga priklaku. Menghindari hal-hal yang kurang baik tidak hanya ditekankan pada masa kehamilan saja, akan tertapi juga sampai dewasa. Sebab orang tua memegang peranan penting dalam menanamkan perilaku dan adab serta akhlak yang baik kepada anak-anaknya. Jika orang tua khususnya ibu berprilaku baik, maka diharapkan sang anak juga meniru serta mencontoh perilaku baik dari orang tuanya.Kelima, membacakan do'a. Do'a seorang ibu sangat ampuh untuk mengantarkan kesuksesan serta perbuatan sang anak. Dengan berdo'a sesedorang tidak saja akan tersugesti dengan do'anya, tetapi juga akan termotivasi menjadi seorang yang kuat, penuh optimis dan memiliki harapan pasti serta melakukan aktivitas-aktivitas yang baik. Oleh karena itu sangat relevan sekali bila doa dijadikan metode untuk mendidik anak dalam kandungan. Dalam berdo'a anak yang masih dalam kandungan hendaklah dikikutsertakan melakukan berdoa bersama-sama, baik dengan ibu ataupun ayahnya.

\section{Pola Asuh Ibu dalam Mendidik Anak}

Pola asuh merupakan hal yang mendasar dalam pembentukan karakter.Teladan sikap orang tua sangat dibutuhkan bagi perkembangan anak-anak karena anak-anak melakukan modeling dan imitasi dari lingkungan terdekatnya. Keterbukaan antara ibu dan anak menjadi hal penting agar dapat menghindarkan anak dari pengaruh negatif yang ada di luar lingkungan keluarga. Orang tua perlu membantu anak dalam mendisiplinkan diri mengisi waktu luang anak dengan kegiatan positif untuk mengaktualisasikan diri penting dilakukan. (Sochib, 2000). Pengisian waktu luang juga merupakan salah satu wadah "kartasis emosi" Di sisi lain ibu hendaknya solid dan konsisten dalam menegakkan aturan. Apabila ayah dan ibu tidak solid dan konsisten dalam menegakkan aturan, maka anak akan mengalami kebingungan dan sulit diajak disiplin.

Pola asuh Ibu dibedakan menjadi tiga jenis, yaitu (a) pola asuh otoriter;(b) pola asuh demokratis; (c) pola asuh permisif. Pola asuh otoriter mempunyai karakteristik, yaitu Ibu yang membuat semua keputusan, anak harus tunduk, patuh dan tidak boleh bertanya. Pola asuh demoratis mempunyai karakteristik, yaitu Ibu mendorong anak membicarakan apa yang ia inginkan. Sedangkan pola asuh permisif mempunyai ciri yaitu Ibu berkewajiban untuk memberikan contoh/teladan, memberitahu dan atau membiasakan, berperan serta atau terlibat dan memberikan wewenang dan tanggung jawab pada anak.

Mendidik karakter anak bukanlah suatu perkara yang mudah.Ibu yang keliru dalam mengasuh anaknya akan menghasilkan "produk" anak yang membangkang, tidak dapat menghormati orang lain, tidak mengenal tata krama atau sopan santun, dan lain-lain. Berikut beberapa faktor cara asuh yang dapat menjadikan anak menjadi produk yang salah dan tidak diharapkan oleh orang tua.Pertama, kurangnya pengawasan. Pada umumnya anak yang salah asuh adalah mereka yang kurang mendapat pengawasan dari orang tuanya. Ibu yang memiliki kesibukan yang sangat padat dipastikan akan mengabaikan anaknya dan tidak memiliki waktu untuk mendengarkan apa kata hati dan keinginan mereka.

Anak yang mulai mengerti dan penasaranakan banyak bertanya. Apalagi jika anak tersebut mulai menginjak masa remaja.Hal itu dilakukan untuk membuka perasaannya yang kecil untuk dapat mengetahui kehidupan yang luas.Anak yang banyak bertanya sebaiknya kita respon dengan kata-kata yang sesuai dengan usianya agar tidak menimbulkan suatu masalah.Ibu tidak boleh memarahi ataupun melarang apabila anaknya banyak bertanya. Sebaiknya jika anak bertanya hendaknya kita menjawabnya dengan persepsi yang berbeda agar si anak tidak berpikiran buruk, karena biasanya anak mempunyai rasa penasaran yang tinggi. Kita harus mengajarkan pada anak agar siap dalam kondisi apapun yang mungkin akan dilaluinya. Diharapkan Ibu mampu memberikan situasi yang berbeda agar anak lebih berani dalam segala hal.

Pemenuhan materi yang berlebihan sangat berperan mempengaruhi pendidikan karakter anak. Jika anak sudah dibiasakan dalam kehidupan materi, biasanya kepribadiannya akan menjadi individualis dan tidak peduli sesamanya. Ibu sebaiknya mengajarkan anak tentang kemandirian dan 
kesederhanaan agar anak tidak terbiasa dengan materi yang berlebihan. Anak harus dibiasakan hidup sederhana dan dihadapkan pada kesulitan dan problem yang berkaitan materi, misalnya prilaku hemat, menabung, dan hanya membeli barang yang diperlukan untuk menunjang keperluan sekolah. Ibu juga harusmengenalkan dan mengajarkan anak tentang peduli sesama yaitu suatu tindakan yang baik dimana anak dapat lebih menyesuaikan diri di masyarakat, suka menolong, dan anak dapat merasakan penderitaan orang lain.

Karakter akan terbentuk sebagai hasil pemahaman 3 hubungan yang pasti dialami setiap manusia (triangle relationship), yaitu hubungan dengan diri sendiri (intrapersonal), dengan lingkungan (hubungan sosial dan alam sekitar), dan hubungan dengan Tuhan YME (spiritual). Setiap hasil hubungan tersebut akan memberikan pemaknaan/pemahaman yang pada akhirnya menjadi nilai dan keyakinan anak. Cara anak memahami bentuk hubungan tersebut akan menentukan cara anak memperlakukan dunianya. Pemahaman negatif akan berimbas pada perlakuan yang negatif dan pemahaman yang positif akan memperlakukan dunianya dengan positif. Untuk itu, Ibu perlu menumbuhkan pemahaman positif pada diri anak sejak usia dini, salah satu caranya adalah dengan memberikan kepercayaan pada anak untuk mengambil keputusan untuk dirinya sendiri, membantu anak mengarahkan potensinya dengan begitu mereka lebih mampu untuk bereksplorasi dirinya sendiri, tidak menekannya baik secara langsung atau secara halus, dan seterusnya. Biasakan anak bersosialisasi dan berinteraksi dengan lingkungan sekitar.Pilihan terhadap lingkungan sangat menentukan pembentukan karakter anak. Sebagaimana sabda Rasulullah, "Bergaul dengan penjual minyak wangi akan ikut wangi, bergaul dengan pandai besimaka percikan atau bunga api akan mengenai kita. Seperti itulah, lingkungan baik dan sehat akan menumbuhkan karakter sehat dan baik, begitu pula sebaliknya.

Hal yang tidak bisa diabaikan dalam pembangunan karakter anak adalah membangun hubungan spiritual dengan Allah Swt. Hubungan spiritual dengan Allah Swt. Akan terbangun melalui pelaksanaan dan penghayatan ibadah ritual yang terimplementasi pada kehidupan sosial. (lihat selengkapnya pendidikankarakter.com/2012/07/04). Pendidikan yang menstimulasi perkembangan karakter anak pada intinya berisi tentang kajian yang berkenaan dengan norma dan nilai yang bermuara pada pembentukan moral. Lingkungan terdekat anak orang tua dan pendidik, mensosialisasikan norma dan nilai dalam berbagai konteks dan cara. Lebih lanjut dijelaskan bahwa setiap aktifitas pengasuhan dan pendidikan yang berorientasi kepada anak hendaknya bermuatan aktifitas belajar yang tidak hanya melibatkan aspek kognitif saja melainkan juga melibatkan aspek afektif, serta sosial dan moral.

Berkenaan dengan pembentukan karakter anak, ada lima hal yang dipertanyakan sebagai dasar untuk mengevaluasi proses pendidikan yang diterima anak, yaitu 1) bagaimana lingkungan memperlakukan anak 2) bagaimana lingkungan terdekat (orang tua dan pendidik) memperlakukan orang lain ketika anak berada pada situasi tersebut 3) apakah ada harapan untuk membentuk karakter yang baik pada anak dan lingkungannya, baik di dalam keluarga maupun di sekolah 4) apakah anak diberi kesempatan untuk mempraktikkan karakter yang baik? 5) apakah ada kerjasama antara orang tua dan pihak sekolah?Lima pertanyaan ini pada intinya bermuara pada lingkungan sekitar anak. Sebagai pendidik yang baik, seorang ibu harus memperhatikan dan menempatkan anak pada lingkungan yang baik, baik lingkungan bermain, lingkungan keluarga, lingkungan masyarakat, dan lingkungan sekolah. Lingkungan yang baik akan memberikan kesempatan pada anak untuk menumbuhkembangkan potensi dan karakter anak dengan baik pula. Sebab, lingkungan juga berperan serta menampilkan model, model yang baik atau jelek. Anak akan terlatih dan terbiasa meniru atau mencontoh model yang dilihatnya secara bertahap. Memberikan lingkungan yang baik bagi anak merupakan tanggung jawab utama bagi Ibu.

Selanjutnya menurut Megawangi (2003), ada tiga hal kebutuhan dasar anak yang harus dipenuhi, yaitu maternal bonding, rasa aman dan stimulasi fisik dan mental. Maternal bonding (kelekatan psikologis dengan ibunya) merupakan dasar penting dalam pembentukan karakter anak karena aspek ini berperan dalam pembentukan dasar kepercayaan kepada orang lain (trust) pada anak. Kelekatan ini membuat anak merasa diperhatikan dan menumbuhkan rasa aman sehingga 
menumbuhkan rasa percsaya. Selain itu anak memerlukan rasa aman, yaitu lingkungan yang stabil dan aman. Lingkungan yang berubah-ubah akan membahayakan perkembangan emosi anak. Anak juga memerlukan stimulasi fisik dan mental dalam pembentukan karakter anak sehingga anak bisa tampil lebih percaya diri

\section{METODE PENDIDIKAN KARAKTER PADA ANAK USIA DINI}

Penanaman nilai-nilai karakter diberikan melalui metode keteladanan, pembiasaan dan pengulangan dalam kehidupan sehari-hari. Suasana dan lingkungan yang aman dan nyaman, perlu diciptakan dalam proses penanaman nilai-nilai karakter. Penanaman nilai karakter pada anak bukan hanya sekadar mengharapkan kepatuhan, tetapi harus disadari dan diyakini oleh anak sehingga mereka merasa bahwa nilai tersebut memang benar dan bermanfaat untuk dirinya dan lingkungannya. Dengan demikian mereka termotivasi dari dalam diri untuk menerapkan dan terus memelihara nilai tersebut dalam kehidupan sehari-harinya..

Cara-cara atau metode tersebut harus dapat membantu ibu dalam melaksanakan pendidikan karakter/ pembinaan akhlak Tanpa adanya metode yang sesuai dengan pendidikan karakter, maka pelaksanaan pendidikan karakter tidak akan berjalan dengan lancar dan tidak akan berhasil dengan baik.

Menurut Langgulung dalam Yunus, (1983:34) bahwa penggunaan metode didasarkan pada tiga aspek,yaitu sebagai berikut :

1. Sifat dan kepentingan yang berkenaan dengan tujuan utama pendidikan Islam, yaitu pembinaan manusia mukmin yang mengaku hamba Allah SWT.

2. Berkenaan dengan metode yang betul-betul disebutkan dalam Al Qur'an atau disimpulkan daripadanya.

3. Membicarakan tentang pergerakan (motivation) dengan disiplin dalam istilah Al Qur'an disebut ganjaran dan hukuman.

Para ahli pendidikan Islam seperti Muhammad Quthb, Abdurrahman al Nahlawi dan Abdullah Nashih Ulwan (Noer,1999 : 117-205), telah mengemukakan metode-metode pendidikan dalam Islam. Diantaranya yang terpenting ialah sebagai berikut :

1. Metode Keteladanan

Pendidikan dengan teladan berarti pendidikan dengan memberi contoh,baik berupa tigkah laku, sifat,cara berpikir dan sebagainya. Banyak ahli pendidikan yang berpendapat bahwa pendidikan dengan teladan merupakan metode yang paling berhasil guna. Hal ini, karena dalam belajar,orangpada umumnya lebih mudah menangkap yang kongkrit ketimbang yang abstrak. Nashih,(1992:50) umpamanya mengatakan bahwa pendidik akan merasa mudah mengkomunikasikan pesannya secara lisan. Anjuran bagi pendidik agar memberikan teladan yang baik sebagaimana Firman Allah Swt dalam surat Al- Ahzab/33 ayat 21.Dalam Psikologi, kepentingan penggunaan keteladanan sebagai metode pendidikan didasarkan atas adanya insting (gharizah) untukberidentifikasi dalamdiri setiap manusia yaitu dorongan untuk menjadi sama (identik) dengan tokoh identifikasi (identificant). Menurut Robert R. Sears dan kawan-kawan (dalam Noer, 1999:180), menyatakan bahwa identifikasi adalah mencakup segala bentuk peniruan peranan yang dilakukan seseorang terhadap tokoh identifikasinya. Dengan kata lain, identifikasi merupakan makanisme penyesuaian diri yang terjadi malalui kondisi interaksional dalam hubungan social antara individu dan tokoh identifikasinya. Pada anak-anak, identifikasi mempunyai arti yang sangat penting bagi perkembangan kepribadiannya.

Ibu sejatinya adalah pendidik utama dan pertama dapat menjadikan dirinya sebagai contoh yang terbaik bagi anak-anaknya. Cara Ibu berbicara, berprilaku, pribadinya, beribadah, beramal, bekerja, dan hubungan sosial dengan orang lain akan dicontoh anaknya. Sebaiknya ibu mengarahkan identifikasi tersebut kepada tujuan pendidikan Islam, mempersiapkan dirinya sebagai tokoh identifikasi,dan menyiapkan atau menciptakan tokoh identifikasi sesuai dengan tujuan 
pendidikan Islam,baik tokoh sejarah maupun tokoh cerita,baik melalui gambar,lisan ataupun tulisan.

\section{Metode Pembiasaan}

Menurut MD Dahlan dalam Noer (2003:154) pembiasaan merupakan proses penanaman kebiasaan kebiasaan.Yang dimaksud dengan kebiasaan (habit) ialah cara-cara yang bertindakyang persistent,uniformdan hampir-hampir otomatis (hampir-hampir tidak disadari oleh pelakunya. Pembiasaan merupakan salah satu metode pendidikan yang sangat penting terutama bagi anakanak.Pada dasarnya anak-anak belum mengerti dan memahami mana yang baik dan buruk dan anak-anak dengan mudah melupakan hal-hal yang baik yang baru saja mereka lakukan. Dalam kondisi ini mereka perlu dibiasakan dengan tingkah laku dan keterampilan, kecakapan dan pola pikir tertentu. Anak perlu dibiasakan melakukan hal-hal yang baik secara teratur, shalat, mengaji, berkata dan berprilaku santun, bekerja, belajar, membaca, mandi, makan dan tidur secara teratur dan sebagainya.

Seseorang yang telah mempunyai kebiasaan tertentu akan dapat melaksanakan sesuatu dengan mudah dan dengan senang hati. Bahkan segala sesuatu yang telah menjadi kebiasaan dalam usia muda sulit untuk diubah dan tetap berlangsung sampai hari tua. Untuk mengubahnya seringkali diperlukan terapi dan pengendalian diri yang serius. Oleh karena itu, pembiasaan yang baik perlu ditanamkan pada anak-anak sejak dini.Gazalba (1980:20) mengtakan bahwa kebiasaan itu dituntut dalam pengaruh pembinaan watak dan tingkah laku. Anak-anak harus dibiasakan sejak kecil dengan kebiasaan yang baik. Selanjutnya menurut al-Taumy al-Syaibany (Rianawati, 1995:17), mengatakan bahwa berulang-ulang insan membuat sesuatu pekerjaan boleh menumbuhkan minat, kecenderungan dan sebagainya. Kecenderungan akhirnya menjadikan adat dan adat yang menumbuhkan kelakuan. Adat berpengaruh besar dalam menumbuhkan kehidupan insan dan kumpulan, baik dari sudut fisik, akhlak, maupun kelakuan. Pembentukan sikap, pembinaan moral, dan pribadi pada umumnya, terjadi melalui pengalaman sejak kecil dan merupakan unsur penting dalam pribadinya.

\section{Metode Nasehat}

Abdurrahman al-Nahlawi dalam Noer (2003:192) mengatakan bahwakata nasehat, berakar pada kata nashaha dan mengandung pengertian bersih dari noda atau tipuan . Rajulun nashih al jaib berarti madu murni. Atas dasar pengertian ini,nasehat yang tulus adalah orang yang memberi nasehat tidak berorientasi kepada kepentingan material pribadi. Selanjutnya pendidik yang memberi nasehat secara tulus hendaknya menghindarkandiri dari segala bentuk sifat riya' dan pamrih agar tidak menodai keikhlasannya sehingga kewibawaan edukatif dan pengaruhnya terhadap jiwa peserta didik menjadi hilang. Selanjutnya menurut Abdurrahman al-Nahlawi lagi dalam Noer (2003:191), metode nasehat adalah penjelasan tentang kebenaran dankemaslahatan dengan tujuan menghindarkan orang yang dinesehati dari bahaya serta menunjukkannya ke jalan yang mendatangkan kebahagiaan dan manfaat.

Memberi nasehat merupakan salah satu metode penting dalam pendidikan Islam.Dengan metode ini Ibu dapat menanamkan pengaruh yang baik ke dalam jiwa apabila digunakan dengan cara yang baik dan bijaksana. Bahkan,dengan metode ini Ibu mempunyai kesempatan yang luas untuk mengarahkan anakpada kebaikan dan kemaslahatan serta kemajuan masyarakat dan ummat.

Dalam menyampaikan nasehatpun diperlukan beberapa cara,agar anak tidak bosan mendengarkannya. Oleh karena itu Nashih, (1988: 77, 105,111 dan 113) memberikan beberapa cara dalam menyampaikan nasehat. Adapun cara-cara tersebut adalah sebagai berikut:

a. Menceritakan suatu kisah yang mengandung pelajaran

Maksud memberikan nasehat dengan cara ini adalah menasehati anak dengan menceritakan kisah atau sejarah kehidupan orang-orang yang berilmu dan bertakwa. Diharapkan agar anak dapat mencontoh sikap dan tingkah laku yang diceritakan.

b. Menggunakan dialog dan tanya jawab 
Maksud nasehat dengan cara berdialog dan tanya jawab adalah menasehati anak dengan mengajak anak untuk bertukar pikiran tentang suatu persoalan kehidupan manusia.

c. Nasehat rumus dan penjelasan

Maksud nasehat dengan rumus dan penjelasan adalah menyampaikan atau memaparkan pesanpesan pendidikan dengan cara membuat skema, sehingga jelas dan mudah diterima oleh akal. Rasulullah sering menjelaskan sesuatu pada para sahabat dengan cara-cara membuat garis-garis atau skema untuk memperjelas masalah yang harus dibicarakan.

d. Nasehat dengan memberikan contoh

Maksud memberikan nasehat dengan disertai dengan contoh adalah memberikan nasehat dengan menggunakan perumpamaan atau pepatah. Berdasarkan uraian di atas, orang tua selalu memberikan nasehat dengan berbagai cara, terutama nasehat dengan memberikan perumpamaan atau dengan menceritakan kisah-kisah orang jaman dahulu yang berkaitan dengan akhlak.

Memperhatikan ulasan di atas, anak-anak usia dini pada dasarnya tidak bisa memahami makna yang terkandung dalam nasehat Ibu. Oleh sebab itu, ibu dapat menggunakan teknik memberi nasehat dengan contoh, menceritakan riwayat para Nabi dan tokoh-tokoh Ulama Islam pada masa Nabi dan jaman sesudahnya. Dengan teknik ini, anak lebih mudah memahami dan meresap hikmah nasehat Ibu.

\section{Metode Pengawasan}

Dalam Kamus Besar Bahasa Indonesia,pengertian mengawasi adalah "Melihat dan memperhatikan (tingkah laku) dan mengamati-amati dan menjaga baik-baik, mengontrol" (Poerwadarminta,1991:68). Menurut Nashih (1992: 128), mengawasi dalam pendidikan adalah mendampingi anak dalam upaya membentuk Aqidah moral. Mengawasinya dalam mempersiapkan secara psikis dan sosial, serta menanyakan secara terus menerus tentang keadaannya,baik dalam hal pendidikan jasmaninya maupun dalam belajar.

Berdasarkan pendapat di atas, mengawasi adalah segala upaya pendidikan yang dilaksanakan oleh pendidik dengan cara memperhatikan dan mengontrol proses pendidikan anak, baik dalam pendidikan keimanan, ibadah, akhlak, mental, sosial, kesehatan maupun seksual anak-anak. Dalam surat al-Tahrim/66 ayat 6 , Allah SWT, telah menyerukan kepada orang-orang yang beriman untuk mendidik keluarganya dengan baik, agar terhindar dari api neraka. Makna inplisit yang terkandung dalam ayat ini, menyatakan bahwa pengawasan adalah salah satu aspek yang sangat penting untuk memelihara dan menjaga tingkah laku anak agar terhindar dari berbagai kesalahan. Dalam banyak hadits, Rasulullah selalu memperhatikan sahabat-sahabatnya dan memberikan peringatan kepada mereka apabila mereka berbuat kesalahan serta memberikan semangat kepada mereka yang berbuat baik. (Nashih, 1988: 127)

Tujuan Ibu melakukan pengawasan adalah agar Ibusegera mengetahui lebih dini kesalahan atau penyimpangan prilaku anak dan segera mengatasinya.. Pengawasan dilakukan dalam rangka antisipasi pelanggaran akhlak yang lebih parah. Dengan pengawasan tindakan prepentif segera dapat dilaksanakan. Pengawasan hendaknya dilakukan oleh Ibu meskipun secara berangsurangsuranak harus diberi kebebasan untuk mandiri.

\section{Metode Hukuman}

Menurut Kamus Besar Bahasa Indonesia, kata Hukum berarti keputusan (pertimbangan) (Poerwadarminta, 1976:339). Menurut Siahaan (1991:55), "Tujuan memberikan hukuman adalah mengajar dan mendorong anak untuk menghentikan sendiri tingkah lakunya yang salahdengan memberikan kesempatan mengarahkan atau mengendalikan diri anak. Dengan demikian,metode pendidikan dengan hukuman adalah suatu cara atau tindakan yang berupa sangsi terhadap prilaku negatif,sehingga prilaku negatif tidak diulangi oleh anak.

Hukuman sangat diperlukan bilamana keadaan tingkah laku anak serius, karena mungkin bisa berbahaya bagi dirinya sendiri dan bagi orang lain.Kebanyakan para ahli pendidikan Islam 
mengatakan bahwa tidak boleh menggunakan metode hukuman kecuali pada keadaan yang sangat diperlukan. Sebelum menggunakan cara ini, pendidik terlebih dahulu menggunakan cara yang halus berupa nasehat, peringatan, dan teguran. Bila cara-cara ini telah digunakan dan anak masih menunjukkan sikap yang negatif, maka metode hukuman dapat digunakan.Menurut Muhammad 'Athiyyah al-Abrasyi (dalam Noer,2003:200), menyatakan bahwa hukuman adalah metode yang terburuk, tetapi dalam kondisi tertentu harus digunakan. MenurutNashih (1981:166-168), bahwa ada beberapa persyaratan dalam memberikan hukuman, yaitu sebagai berikut:

a. Hukuman adalah metode kuratif. Tujuan diberikannya hukuman adalah untuk memperbaiki peserta didik yang melakukan kesalahan dan memelihara peserta didik lainnya, bukan untuk balas dendam. Oleh sebab itu, pendidik tidak menjatuhkan hukuman dalam keadaan marah.

b. Hukuman baru dilaksanakan, bila metode-metode yang lainnya sudah dilaksanakan, seperti metode nasehat, pengarahan, memberi isyarat dan membujuk.

c. Sebelum dijatuhkan hukuman, diharapkan peserta didik mengerti dan memahami mengapa hukuman itu dijatuhkan kepadanya dan tidakmengulangi perbuatannya lagi.

d. Sebelum hukuman dilaksanakan, anak diberikan kesempatan untuk bertaubat terlebih dahulu.

e. Hukuman yang bersifat psikis lebih baik ketimbang hukuman fisik. Artinya, anak dapat diberikan sangsi-sangsi lainnya daripada dihukum.

f. Dalam menjatuhkan hukuman, hendaknya diperhatikan aspek psikologis anak yaitu hukuman disesuaikan dengan jenis kesalahan.

g. Pendidik hendaknya tidak mengeluarkan ancaman hukuman yang tidak mungkin dilakukan. Misalnya bila anak tidak membuat PR, maka pendidik akan memberikan hukuman yang lainnya, hal ini tidak akan membuat peserta didik jera atas tindakan negatifnya.

h. Pendidik tidak perlu terburu-buru menggunakan metode hukuman,kecuali bila sudah menggunakan metode yang lain,misalnya metode nasehat.

i. Ketika memukul,hendaknya menghindari anggota badan yang peka, seperti kepala, muka, dada, dan perut.

j. Pukulan pertama untuk hukuman,hendaknya tidak terlalu keras dan tidak menyakitkan pada kedua tangan atau kaki dengan (lidi/rotan)

k. Pendidik hendaknya menghukum anak dengan tangan sendiri dengan kata lain tidak menyerahkannya pada tangan orang lain.

Pemberian hukuman atau sanksi pada anak usia dini harus lebih berhati-hati. Hukuman tidak dikenakan ketubuh anak, akan tetapi anak diberikan suatu aktivitas yang sesuai dengan usianya. Atau hukuman bisa berupa meniadakan sementara hal-hal yang disukai anak. Misalnya sementara waktu anak tidak boleh bermain, anak disuruh tidur, atau makan/minum sesuatu (menyehatkan) tetapi anak tidak menyukainya. Bila anak mendapat hukuman dengan sesuatu yang tidak disukainya, kemungkinan anak akan jera untuk mengulangi kesalahannya.Islam telah memberikan batasan, bahwa hukuman hanya bersifat untuk pendidikan saja. Dengan demikian pendidik tidak boleh memberikan pukulan yang dapat membahayakan anak.

\section{AZAS YANG HARUS DIMILIKI ORANG TUA SEBAGAI PENDIDIK}

Menurut Kamus Besar bahasa Indonesia, defenisi Asas adalah "Dasar (sesuatu yang menjadi tumpuan berpikir atau berpendapat)" (Poerwadarminta,1976:60). Yang dimaksudkan dengan asas disini adalah asas-asas yang harus dimiliki orang tua khususnya Ibusebagai dasar dalam mendidik. Ada pun yang menjadi dasar dalam mendidik itu adalah sifat taqwa, sifat ikhlas, sifat santun, sifat tanggung jawab, dan ilmu. Di bawah ini akan diuraikan satu persatu dari asas-asas pendidikan.

1. Takwa

Takwa adalah menjaga diri dari azab Allah dengan mengerjakan amal shaleh dan merasa takut kepada-Nya, baik secara sembunyi-sembunyi maupun terang-terangan. (Nashih,1988:178). 
Dengan demikian, takwa adalah berusaha semaksimal mungkin untuk melaksanakan perintah Allah dan meninggalkan segala larangan-Nya, sebagaimana Allah Swt dalam surat Ali-'Imran ayat 102 : "Hai orang-orang beriman, bertakwalah kepada Allah sebenar-benarnya takwa kepada Allah" (Q.S. al-'Imran/3 :102)

\section{Sifat Ikhlas}

Menurut Kamus Besar Bahasa Indonesia, Ikhlas adalah dengan "Senang hati (jujur): tulus hati". Dengan demikian, ikhlas adalah melakukan sesuatu pekerjaan atau perbuatan dengan senang hati dan benar-benar tulus hati. Nashih (1988 : 174), menyatakan bahwa seorang pendidik berniat dan mencurahkan seluruh aktivitasnya dibidang pendidikan. Sedangkan M. Ali Hasyimi (1992:16), menyatakan bahwa keikhlasan dalam ibadah (mendidik anak), bagai semerbak bunga-bunga, bau wangi inilah yang menjadikan amal ibadah seseorang istimewa dan tinggi derajadnya. Perintah untuk mengerjakan sesuatu perbuatan dengan sifat ikhlas adalah berdasarkan firman Allah Swt. Dalam surat Al-Bayyinah/98 ayat 5.

\section{Sifat Santun}

Menurut Kamus Bahasa Indonesia arti kata santun adalah "Halus dan baik (budi bahasanya, tingkah lakunya) sopan, sabar, dan tenang. (Poerwadarminta, 1976:878).Dengan demikian yang dimaksud dengan sifat santun adalah suatu sifat yang menunjukkan tingginya budi pekerti yang dimiliki oleh seseorang karena kesopanannya, kesabarannya, dan ketenangannya. (Nashih ,1992 : 186), menyatakan bahwa seorang pendidik khususnya orang tua, harus memiliki sifat santun yang berarti orang tua khususnya ibu harus berjiwa kuat dan tidak mudah emosional dalam upaya meluruskan dan memperbaiki akhlak anak. Selain itu Hasyimi (1992:54), menyatakan bahwa seorang muslim yang benar (sadiq), tidaklah marah kecuali mudah pula reda kemarahannya. Kesantunan adalah unsur utama spiritual dan moral yang dapat menunjukkan tingginya akhlak seseorang sebagaimana Firman Allah Swt. dalam surat AlSyura/26: 43.

4. Sifat Tanggung Jawab

Menurut Kamus Besar Bahasa Indonesia, arti kata tanggung jawab adalah keadaan wajib menanggung segala sesuatunya (kalau terjadi apa-apa boleh dituntut, dipersalahkan, diperkarakan, dsb) (Depdikbud, 1992 : 1006). Jadi tanggung jawab adalah suatu sifat yang menjaga sesuatu atau melaksanakan sesuatu dengan sebaik-baiknya, karena ada sesuatu tuntutan pada batinnya, apabila sesuatu itu tidak dijaga atau dilaksanakan. Ayat Al-Qur'an yang mendasari tanggung jawab adalah firman Allah Swt. Sebagaimana surat al-Saffat/37 : 24.

5. Ilmu

Menurut Kamus Besar Bahasa Indonesia arti kata ilmu adalah pengetahuan atau kepandaian (tentang soal dunia, akhirat, lahir, batin dan sebagainya) (Poerwadarminta, 1992 : 371). Jadi ilmu adalah seperangkat pengetahuan yang dimiliki oleh seseorang. Menurut Nashih (1981:180) dikatakan bahwa seorang pendidik khususnya ibu, seyogyanya mengetahui dasar-dasar pendidikan yang dicanangkan oleh syariah Islam, mengetahui masalah halal dan haram, berakhlak baik, memahami secara global peraturan-peraturan Islam dan kaidah-kaidah Syariah Islam. Jika orang tua tidak memiliki ilmu pengetahuan, apalagi tentang kaidah-kaidah asasi dalam pendidikan Islam, maka anak akan dilanda kemelut spiritual dan moral. Oleh karena itu hendaklah para orang tua berusaha dan membekali dirinya dengan ilmu pengetahuan yang berpijak pada ajaran Islam.Menuntut ilmu merupakan suatu kewajiban.

\section{PENUTUP}

Peran ibu dalam pendidikann anak usia dini, sangatlah beragam dan berbagai solusi menuju pembentukan karakter pada usia dini. Pendikan karakter melalui penerapan prilaku akhlak mulia 
dan pengenalan pada Allah sejak usia dini, cara berfikir masih operasional kongkrit, maka dalam implementasinya dengan landasan akhlak mulia harus dilakukan dengan contoh-contoh yang kongkrit/nyata.

Seorang ibu dalam melakukan pengasuhan pada anakm usia dini, diajak meniru sesuatu yang sangat berkesan dan anak diajak berfikir tentang ciptaan Allah dengan landasan kasih sayang. Pengenalan kepada Allah bisa dikenalkan dengan anak melalui do'a yang sederhana, melalui bentuk bentuk ciptaaan Allah yang dia kagumi.Melalui pendidikan karakter secara sederhana, Ibu dapat menyelami jiwa anak dan memberikan cinta kasih sayang setulus-tulusnya.

Pendidikan karakter bukan sekedar mengajarkan mana yang benar dan mana yang salah, lebih dari itu, pendidikan karakter menanamkan kebiasaan (babination) tentang hal-hal yang baik sehingga anak menjadi paham (cognitive) tentang yang benar dan salah, mampu merasakan (afektif) nilai yang baik dan biasa melakukannya (psikomotor). Dengan kata lain, pendidikan karakter terhadap anak usia dini haarus melibatkan bukan saja aspek pengetahuan yang baik (moral knowing), akan tetapi juga "merasakan dengan baik" (moral feeling) dan "prilaku yang baik" (moral action). Pendidikan karakter pada anak usia dini lebih menekankan pada babit atau kebiasaan yang terus menerus dipraktekkan dan dilakukan.Pendidikan merupakan suatu usaha dimana adanya kesadaran untuk mengembangkan potensi diri dalam memahami suatu pengetahuan untuk dapat dimengerti. Pendidikan sangat penting diterapkan pada anak.Sebaiknya Ibu yang memberikan pendidikan karakter secara langsung mulai dari kecil kepada anak. Anak sebaiknya diberi pengetahuan yang baik.

Ibu sebaiknya mendidik anak dengan tanggung jawab dan kedisiplinan. Tanggung jawab sangat diperlukan dalam mengembangkan kepribadian anak. Ibu harus mengajarkan tentang arti akhlak mulia, shalat, puasa, mengaji, mencari tahu tentang prilaku para Nabi dan tokoh-tokoh Ulama jaman dahulu dari kisah-kisah yang terdapat dalam Al-Qur'an dan riwayat hadits, bersedekah, berbuat pada orang lain, tangung jawab, displin, dan lain-lain. Berbagai metode dapat Ibu gunakan agar pendidikan karakter dapat tercapai dengan baik. Peran Ibu sangatlah penting dalam memberikan perhatian dan kasih sayang karena itu sangat diperlukan untuk menjaga suatu hubungan dalam perkembangannya.Selain itu, seorang yang sejatinya adalah pendidik pertama dan utama harus memperhatikan asas-asas dalam pendidikan Islam, yaitu takwa, santun, ikhlas, tanggung jawab, dan memiliki wawasan dalam pendidikan Islam.***

\section{REFERENSI}

Abdullah Nashih Ulwan,1989. Pedoman Pendidikan Anak Dalam Islam, terj. Saifullah Noer Ali.Semarang: Asy Syifa'

Karya.

1992. Mengembangkan Kepribadian Anak, Bandung: Remaja Rosda

Doni Koesoema, 2007. Pendidikan Karakter, Strategi Mendidik Anak di Zaman Global. Jakarta: Grasindo.

Hasan, 2004. Mendidik, Anak Dengan Cinta. Yogyakarta: Saujana.

Mahmud Yunus, 1983. Metodik Khusus Agama Islam, Jakarta : Hidakarya Agung

Megawangi, Ratna, 2003. Pendidikan Karakter untuk Membangun Masyarakat Madani. Indonesia: IPPK Indonesia Heritage Foundation. 
Muhammad Annis Matta, 2003. Membentuk Karakter Cara Islami, Jakarta: Al'Itishom Cahaya Ummat.

Moch. Shocib, 2000. Pola Asub Orang Tua.Dalam Membantu Anak Mengembangkan Disiplin Diri. Rineka Cipta: Jakarta

M. Athiyah Al-Abrasy, (1970). Dasar-dasar Pokok Pendidikan Islam, Jakarta : Bulan Bintang

N. Henry Siahaan, 1986. Peranan Ibu Bapak Mendidik. Anak, Bandung: Angkasa.

Noer, Hery Aly, (1999). Ilmu Pendidikan Islam, Jakarta : Pt. Logos Wacana Ilmu

Pendidikan karakter.com, 2012."Membangun Karakter Sejak Pendidikan Anak Usia Dini”, dalam http:/ / wnw.pendidikankarakter.com/ membangun-karakter-sejak-pendidikan-anak-usia-dini/. Akses internet tanggal 5 November 2013.

Poerwadarminta, (1976). Kamus Umum Babasa Indonesia, Jakarta : Balai Pustaka

Rianawati, "Peranan Ibu Dalam Pendidikan Anak Menurut Pandangan Islam”, Skripsi, IAIN Pontianak, 1995.

Sidi Gazalba, 1980. Pendidikan Umat Islam, Jakarta: Bhatara. 